\title{
Investor-State Dispute Settlement and Indonesian Reform Policy in Mining Downstream Sector
}

\author{
Syahrir Ika ${ }^{1}$, Sigit Setiawan ${ }^{2}$ \\ Fiscal Policy Agency, Ministry of Finance Indonesia, Indonesia \\ sika@fiskal.depkeu.go.id, sigitstiawan@gmail.com
}

\begin{abstract}
To date, Indonesia has been facing the seventh ISDS (Investor-State Dispute Settlement) lawsuit case in ICSID, the most number of ICSID cases a particular country has in ASEAN. In the meantime, Indonesia had to initiate reform in its minerals mining sector policy since the sector had provided little benefit in Indonesian sustainable economic development thus far-a policy reform which is potentially highly exposed to ISDS lawsuit case. Yet, the reform once issued has no turning back and thus it should move forward. Indonesian reform policy to support more its mining downstream by Minerba Act issuance is intended to benefit from its scarce, limited non-renewable minerals so as to support national development and maintain its long-term interest and economic sustainability. Undoubtfully, the policy reform will be beneficial for Indonesian economy sustainability and thus it should be protected from any potential ISDS claims in the future. This study seeks to address such real, critical current challenges arising from contingent ISDS claims towards Indonesia. This study adopts a descriptive analytical method, which combines literature review, authors' shared expertise in this field, and results of interviews and discussions with several other experts in relevant fields. This study concludes that in addressing ISDS contingent problems threatening Indonesian current reform policy in mining downstream sector, Indonesia should focus the emphasis on the prevention endeavor, those are a review of BITs and IIAs containing ISDS provisions; improvement in investment dispute management; which are mainly supported by continuous bureaucracy reform, capacity building, and better coordination.
\end{abstract}

Keywords: ISDS, ICSID, reform policy, mining downstream sector, sustainable economic development

\section{Introduction}

As one of the emerging countries, Indonesia has turned into an attractive investment destination for foreign investors. Domestic and foreign investors keep increasing their investment in line with Indonesian government continued efforts to facilitate permits and ensure legal certainty for investment. However, as time passes by the Indonesian government encounters a situation -normally found in other countries -in which it has to change its policy into a new policy for the purpose of national development. New policies or policy reforms - now and then - are found contradictory with bilateral investment treaties (BITs) or international investment agreements (IIAs). Sometimes this new policy will inevitably have to intersect with previous investment project contracts between the government and foreign investor companies, trigger the dispute arising between foreign investors and government. If they cannot find a win-win solution, the threat to sue the government to international arbitration tribunal becomes something common to hear from foreign investors.

The issuance of Law No. 4 of 2009 on Minerals and Coal (Minerba Act) has become a new policy milestone of Indonesia in promoting mining downstream sectors. (Ika, 2017) mentions four urgencies of promoting mineral downstream policy, i.e. to encourage the establishment of domestic smelters, to integrate upstreamdownstream-industrial operations, to increase mineral added value, and to boost state revenues. On the other hand, this policy has the potential to trigger new investor-state dispute settlement (ISDS) conflicts with foreign mining companies operating in Indonesia under the Contract of Work. In 2014 PT Newmont Nusa

\footnotetext{
${ }^{1}$ Associate Research Professor at Fiscal Policy Agency, MOF Indonesia. Former Human Resources Director (2003-2008) at Aneka Tambang, Co. Ltd. an Indonesian State-Owned Enterprises in Minerals Business Field Sector.

${ }^{2}$ Senior Researcher at Fiscal Policy Agency, MOF Indonesia. Former Indonesian delegate member, a former Indonesian negotiating team member, and a former secretariat member in Indonesian Coordinating Team on Services Sector $(2007$ - 2012).
} 
Tenggara filed a lawsuit to the International Centre for Settlement of Investment Disputes (ICSID) which fortunately was withdrawn. Furthermore, PT Freeport International (PTFI), a US copper and gold mining company operating in Timika, Irian Jaya, also once threatened to bring the dispute with the Indonesian government into international arbitration. Some of PTFI's objections were the clause to change from KK to IUPK (Special Mining Permit) and to undertake 51 percent divestment-a rational resistance since divestment is an unpopular decision that both damage the reputation and the company image both at home and in the host countries (Resmini \& Vittucci, 2016). Unfortunately, the Government of Indonesia remained firm with its stance.

Recent updates inform that Indonesian government and PTFI have reached an agreement as outlined in the Head of Agreement as of July 2018, whereby PTFI approves the above provisions in return for investment contracts to be extended until 2041. Another compromise is the Government also guarantees divestment obligations and changes in KK status to IUPK will not interfere with the business climate and PTFI long-term plan. However, as confirmed by (Losari \& Ewing-Chew, 2015), the potential for conflict to arbitration is still open since there is still a long way to go between the two parties until implementation is fully implemented. The case of disputes in the mining sector between foreign investors and government is not Indonesian monopoly. Similar cases also occur in other resource-rich countries such as South Africa (Mohamadieh \& Uribe, 2016), Equador, Bolivia, and Venezuela (Berger, 2015). If there is no common ground in the case of an investment dispute, then the investor brings the case into international arbitration for investor-state settlement (ISDS). Those ISDS-related provisions are commonly found in Bilateral Investment Treaties (BITs) and International Investment Agreements (IIAs) ${ }^{3}$ i.e. Investment Chapters under various Free Trade Agreements (FTAs). Indonesia took part in 64 BITs and five IIAs, i.e. Investment Chapters of FTAs and were therefore obliged to the ISDS-related rules under the treaties or chapters. Currently, Indonesia is terminating several BITs and reviewing others (Jailani, 2015).

This study has several objectives. The first objective is to briefly describe the history of ISDS scheme existence in international treaties, the emergence of ISDS cases including cases that affect Indonesia. Secondly, this study will analyze the rationale of policy reform in mining downstream sector which potentially triggers ISDS dispute with foreign investors in the mining sector. In the final section, this study will examine the various challenges encountered in benefiting the ISDS mechanism and some of the possible solutions that Indonesia has to anticipate in ISDS dispute in the mining sector. This study adopts a descriptive analytical method, which combines literature review, authors' shared expertise in this field, and results of interviews and discussions with several other experts in relevant fields. Some necessary secondary data is compiled from the Ministry of Finance and PTFI.

\section{History of ISDS Mechanism}

The use of ISDS mechanisms among countries in their investment treaty was initiated in the late 1960s and early 1970s. Thirty years later the model agreement with the ISDS mechanism has become the standard investment treaty. Foreign investors who object with the host country's policy may file a dispute lawsuit against an international arbitration institution. The most popular tribunal for arbitration is the New Yorkbased International Center for Settlements of Investment Disputes (ICSID). ICSID, which was established in 1966 and domiciled under the World Bank, currently comprises 162 member countries including Indonesia. The ISDS mechanism was seen as a way out at the time for the problems that foreign investors encountered mostly investors came from European and American countries. Some of the investment was in their former colonies.

Previously without ISDS, foreign investors had two options to reclaim their investment taken over by the host country (UNCTAD, 2014). The first option was to seek justice by filing a lawsuit to a local court or administrative court in the country where the investment was located. But this option was often constrained by the legal protection of local courts over domestic policies issued by the government. It tended biased because local courts saw the government of a sovereign state had privilege and authority over its dosmetic

${ }^{3}$ Subsequently called investment treaty 
policy as long as it was devoted to national or community interest. Others pointed to the judiciary system in developing countries that were sometimes not independent and could be intervened by officials or political figures. If this first option failed, there was the second option in which foreign investors might expect diplomatic protection assistance from their government.

This second option could be a powerful weapon when the country of origin of the investor belonged to a group of "strong" countries, in their politics, economy, and defense in the world; even more so if the country belonged to a group of superpowers such as the United States, Russia, Britain, France and China. Not all "strong" countries were willing to intervene in the interest of their investors. It was often that the expectation from this second option conflicted with consideration and calculation of greater political interests. Investors with large capital were in a more favorable position than small investors, because they had the capital strength that was expected to influentially direct their home country foreign policy in defending their investment interests. Germany became a pioneer country of the ISDS mechanism, making it prominent as the grandfather of investor-state arbitration (Provost \& Kennard, 2015). Germany - in the late 1950s - became the first country to issue the idea of an obligation of investor-state dispute settlement mechanisms existence in investment proposals offered by German investors to developing countries. Germany called the concept of its proposed agreement an "international Magna Carta" - an international charter of constitutional rights protection for private investors. In the 1960s, the German concept was later adopted by the World Bank through the establishment of ICSID. The World Bank decision at the time was not without resistance.

In total 21 World Bank member countries from the developing country group opposed the decision. The opposing group believed that the ISDS mechanism would reduce the country's sovereignty, while the World Bank believed that ICSID would be a fair mechanism for investors willing to invest and in return helping developing country economies. The foreign investment entry would help the developing country create jobs, generate the flow of state revenues in the form of taxes and non-taxes income, and develop the technology. Later in the 1980s, German investors became pioneers by initiating to file lawsuits against dozens of developing countries such as Ghana, Ukraine and the Philippines to ICSID. Indonesia itself does not escape investor claims in ISDS cases. Among ASEAN member countries Indonesia even topped the number of ISDS suits filed in ICSID, above the Philippines with three cases. As indicated in Table 1, the Government of Indonesia itself has received at least seven lawsuits from foreign investors in the direct disputes between foreign investors and Indonesian government (trial at ICSID) and one indirect investment dispute of foreign investors and state-owned enterprises owned by the Indonesian government, the so-called Karaha Bodas case (trial outside ICSID).

Table 1: Indonesia's Involvement in Case before ICSID

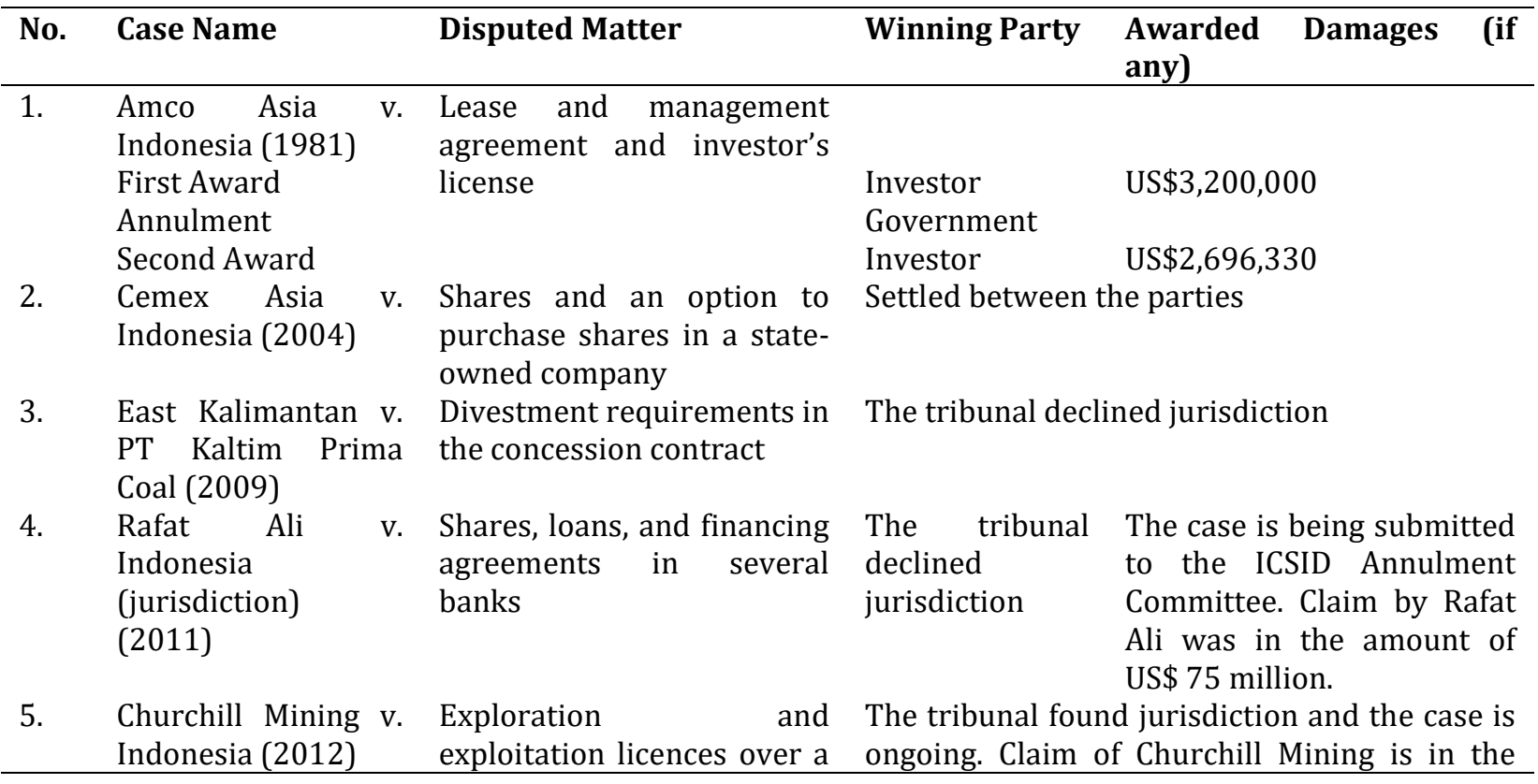




\begin{tabular}{llll}
\hline 6. & Planet Mining v. & Coal Project Area & amount of US\$1.05 billion \\
& Indonesia (2014) & & \\
7. & Nusa Tenggara & Regulation on export ban of & Registered to the ICSID Secretariat on 15 July \\
& Partnership BV and & raw materials & 2014. Withdrawn on 25 August 2014. \\
PT Newmont Nusa & & \\
Tenggara v. & \\
Indonesia (ongoing)
\end{tabular}

Source : Losari \& Ewing-Chew (2015) and Magiera (2017), compiled.

\section{The Rationale of Indonesian Policy Reform in Minerals and Coals Downstream Sectors}

Out of the seven disputes in ICSID involving Indonesia until 2016, only the disputes filed by Churcill Mining and Planet Mining that Indonesia won on the dispute subject, while the Hesham Al Waraq and Rafat Ali Rizvi (the owners of Bank Century) lawsuit - ended with the refusal by ICSID. As a country with the largest land area in Southeast Asia, Indonesia is endowed with rich mineral resources such as nickel, gold, silver, bauxite, copper, and tin. But unfortunately, these wealthy resources cannot be managed optimally to boost state revenue and the welfare of Indonesian people. The prime cause is that most mining companies operate in the upstream and export low-value ore or raw minerals. The practice has lasted for more than 40 years, so that Indonesia then gets the nickname as the exporter of a raw material specialist. Then it is realized that Indonesia has the potential to change its mineral resources into an economic value that is beneficial to national development. Thus, the policy strategy that should be pursued is promoting downstream process or value-adding process in the mineral mining sectors. Downstream process or value-adding process by Patunru, (2015) is an attempt to curtail raw materials export and instead encourage domestic industries to add value to raw materials by producing intermediate or final products while creating jobs at the same time. The above reform to promote mining downstream sectors became one of the main policies launched during President Susilo Bambang Yudhoyono second term (2009-2014). Indonesian Government reformed its national mineral management policy by issuing Law No. 4 of 2009 on Minerals and Coal (Minerba Act).

In addition to the Minerba Act, the government also published a related policy package. The Minerba Act was enacted to bring the main mission to encourage the shifting of mineral management from upstream to downstream sectors. The shifting is encouraged by requiring Mining Business License (IUP) and Contract of Work (KK) holders to build a smelter within the country. The shifting obligation also comes with a ban to export raw minerals to mining companies. This prohibition is regulated in the implementation of Minerba Act, namely Government Regulation (PP) no. 23 of 2010, and came into effect on January 12, 2014 or five years since Minerba Act was enacted. The downstream policy plays an important role in the national development as it becomes one of the government fiscal tools to create added value in minerals, boost state revenues, promote economic growth, create jobs, and to make Indonesian people prosper equitably. The success indicator of downstream mineral policy is Indonesian exported goods will be no longer raw materials, yet finished goods which are manufactured from raw materials. Indonesia will be able to export lipstick or chemical blend, not palm oil any longer; export aluminium products to automotive parts instead of bauxite ore or bauxite concentrate. The economic value added of minerals varies depending on their types (Rudenno, 2004). Bauxite ore, for example, its added value increases 12 times or reach 25 percent to 35 percent when processed into alumina. Bauxite added value can be increased again up to 60 percent, even more through metallurgy process or smelting.

$\mathrm{Ni}$ (nickel) content in a ton of laterite ore reaches about 2 percent. With the metallurgy (smelting) process, the nickel content in ferronickel can be escalated to 15-30 percent. Another example is copper and gold in Papua Island, Indonesia, under PTFI exploration. The content of copper in a ton of ores is only about $0.15-2$ percent, but with smelting process, copper ore content can be escalated to 10-30 times or about 40 percent. The gold content $(\mathrm{Au})$ in a ton of laterite ore only ranges from 1.5-4 grams, whereas through a particular metallurgy process through purification, it can be increased to 99.99 percent. As a mineral resource-rich country, it is an irony that the mining sector in general and mineral mining sector in particular, contributes poorly to state revenues and fails to become an economic pillar for Indonesian people welfare. The relatively small contribution of Indonesian mineral mining sector is not much different from the contribution of its 
mining sector in general which only reaches around Rp 60.42 trillion or 6.16 percent of its total state revenue (API, 2013). Kementerian ESDM, (2015) reports that the contribution of minerals sector to Indonesia's exports and Gross Domestic Product (GDP) is only 3.2 percent and 5.12 percent respectively. ${ }^{4}$

Meanwhile, the contribution of the minerals and coal sector to Non-Tax State Revenue (PNBP) only reaches 4.4 percent (Walker, 2015). Let us compare with Chile - the world's largest copper mineral producer - the contribution of the minerals sector to Chile's total exports and GDP has reached 30 percent and 6.7 percent respectively (Saggu \& Anukoonwattaka, 2015). In fact, Chile is currently exporting concentrate only, not higher value-added products as Indonesia expects to acquire through the mineral downstream policy. Thus, if the Indonesian reform policy succeeds, Indonesia has potentials to boost its state revenue and increase its relative contribution of minerals sector surpassing Chile. Based on the expertise, previous experience, and analysis, Ika, (2017) concluded that Indonesian reform policy to promote mineral downstream policy is based on four urgencies, i.e. to encourage the establishment of domestic smelters, to integrate upstreamdownstream-industrial operations, to increase mineral added value, and to boost state revenues. First urgency, encouraging the establishment of domestic smelters is crucial since the mineral is a non-renewable resource base of national wealth. Because of their non-renewable nature, the management of minerals should be maximized to generate greater value-added for resource owners.

Failure to maximize the wealth of mineral, such as selling only in the form of ores or concentrates, will result in low added value for Indonesia; thus, an obviously big loss to Indonesian people in the long term and inheriting nothing but natural destruction to next generations. To prevent it from happening, the Minerba Act therefore requires mining companies to construct domestic smelters for processing domestic minerals products and prohibits mining companies from exporting ores or raw minerals. The second urgency, the integration of industry-downstream-upstream operations needs to be encouraged in order to keep the balance of overall mining sectors. Given the current lack of added value in the upstream industry, the mining downstream promotion needs to be continuously encouraged in order to contribute greater value added. The challenge is in the upstream-downstream operations integration effort, higher risk factors are found in the downstream compared to upstream risks (see Burmeister (1988), Harquail, (1991) and Ward \& McCarthy, (1999). Thus, a special strategy is required. Lessons learned from the efforts of PT. Antam to synergize mining business in the upstream (nickel ore) and the downstream (ferronickel) is that such a combined policy is proven very vulnerable to be affected by the world nickel price fluctuations.

If the ores price drops in the global market, then two sources of Antam's revenue are both eroded, i.e. the revenue from nickel ore sales and the revenue from ferronickel sales. When the price of nickel ore is high, Antam greatly benefits from the rising price of nickel or ferronickel. When the price of nickel ore in the global market reached the highest level in 2007, Antam recorded the highest profit in its history, which was around Rp5.1 trillion. However, when the price of nickel ore dropped dramatically, the price of ferronickel also slumped so that Antam was greatly disadvantaged. After 2007, the price of nickel ore in the international market has continued to decline, so Antam's profit also continues to erode to negative reach in 2014 and 2015 (Antam, 2015). Industry-downstream integration is seen as having a lower risk compared to downstream-upstream integration, as the downstream business risks are not directly related to the business risks in manufacturing industries. If a stainless steel factory does not get ferronickel supplies from a local smelter, this supply can be provided from other smelters or even from abroad as long as it is affordable. The good news is PT Smelting Gresik (PTSG) has now integrated industry-downstream activities. PTSG has a smelter to process copper concentrate into the copper cathode. PTSG does not operate in the upstream of copper, but operates downstream by receiving copper supplies from PTFI and PT Amman to be processed into copper cathode.

PTSG then sells copper cathode products to the cable industry and fertilizer industry (Petrokimia Gresik). The third urgency is to increase the added value of minerals, because the mineral resources, especially metals will

${ }^{4}$ Kementerian ESDM. Laporan Kinerja Tahun 2015. 
be exhausted and non-renewable. Based on the facts, metal mineral resources need to be processed domestically to produce higher added value, which in turn it can accelerate national economic growth. Mineproducing areas that successfully diversify the economy from each value chain enjoy more success than those areas that neglect economic diversification and continuously depend on the mine. These evidences are the results of studies conducted by Thomas Michel Power, as quoted by Sembiring, (2009). Power studies further find that areas that rely on upstream mining operations tend to experience economic decline and depression, especially after the mine has been exhausted or entering the post-mining phase. Another study conducted by Stijns, (2001) also asserts that countries that opt to export their natural resources rather than utilize them for domestic and manufacturing industries, their economic growth will significantly suffer from negative impact. Reflecting on Stijns, (2001), Indonesia still has problems in optimizing its mineral resources to boost its manufacturing sector and economic growth. Let us take aluminium as an example. Indonesia has substantial aluminium mineral reserves and the state-owned enterprise which operate the exploration (PT Inalum), but unfortunately this aluminium wealth cannot be utilized and optimized to develop its domestic and manufacturing industry. Different cases are found in Australia, where the country has successfully managed its bauxite reserves. Australia has six aluminium smelters scattered in several states (New South Wales, Queensland, Tasmania and Victoria), managed by big companies Rio Tinto, Alcoa, Pechiney, VAW Aluminium AG and a consortium of Japanese companies. The bauxite mineral mixed with other metallic minerals such as chrome, steel, or nickel, will produce excellent aluminium (alloy), which is heat resistant, strong but flexible, and easy to form, so it can be used for automotive, shipbuilding, and aircraft parts manufacturing industry. With the industrydownstream-upstream integration as Australia undertakes, the economic value added obtained is much greater, and so is the tax contribution to the country.

Following the enactment of Minerba Act, Indonesian reform has progressed. To process mineral ores and give more added value to them, so far Indonesia has built 24 operating smelters, consisting of 15 nickel smelters, four iron smelters, two bauxite smelters, two manganese smelters, and one copper smelter. In addition, many other smelters that are currently under construction will follow the operation. The fourth urgency of mineral downstream policy is to optimize the mineral sector contribution to state revenue, both taxes and non-taxes. The potential for high state revenues from mineral resources can only be realized if the government reforms its mineral management policy. The current dependence on mining operations in the upstream sector by exporting mineral ores (nickel, bauxite, copper and iron) has resulted in low state revenue both in tax and non-tax contribution. Therefore it does make sense that Indonesia then requires mining companies to build smelters and ban the export of raw minerals as stipulated in the Minerba Act. As an illustration, PTFI's total contribution to state revenues (dividends, royalties, as well as taxes and other non-taxes) in 2006 amounted to 1.6 billion US dollars, of which 81 percent came from taxes and non-taxes (Table 2). The declining trend in commodity prices in global markets occurring since 2012 has impacted PTFI's revenue, which has continued to decline and even recorded losses. PTFI cannot pay dividends to its shareholders, including the Indonesian government which owns 9.36 percent of PTFI shares.

Table 2: The contribution of PTFI to State Revenues (USD Millions)

\begin{tabular}{llllllllll}
\hline Types & $\mathbf{2 0 0 6}$ & $\mathbf{2 0 0 7}$ & $\mathbf{2 0 0 8}$ & $\mathbf{2 0 0 9}$ & $\mathbf{2 0 1 0}$ & $\mathbf{2 0 1 1}$ & $\mathbf{2 0 1 2}$ & $\mathbf{2 0 1 3}$ & $\mathbf{2 0 1 4}$ \\
\hline $\begin{array}{l}\text { Dividends for } \\
\text { Government }\end{array}$ & 259 & 216 & 49 & 213 & 169 & 202 & - & - & - \\
$\begin{array}{l}\text { Royalty } \\
\text { Taxes and Non-Taxes }\end{array}$ & 146 & 164 & 121 & 128 & 185 & 188 & 76 & 101 & 118 \\
Total & 1294 & 1425 & 1039 & 1013 & 1569 & 1993 & 904 & 383 & 421 \\
\hline
\end{tabular}

Source: Kementerian Keuangan. APBN dan Laporan Realisasi APBN (2006-2014), and Freeport McMoRan Inc. Annual Report, (2006-2014) compiled.

Another illustration is the PT. Antam, which also suffered from decreasing income due to declining mineral prices in the global market. When the nickel price reached its peak in 2007, Antam could earn net profit amounted to Rp5.1 trillion and contributed more than Rp2 trillion to state revenues. After 2007, mineral 
prices in the global market continued to decline so that PT Antam contribution to state revenues dropped to only Rp 111 billion in the first half of 2015. All of these are due to PT Antam dependence on the sales of lower grade nickel ore which is vulnerable to commodity price volatility in the global market. Antam has recently changed its strategy and has shifted its business further to the downstream. Antam currently has five operating smelters (three nickel, one alumina and one gold smelters) and is building four other smelters, the Pomalaa Ferronickel Expansion Project (P3FP), the Halon Ferronickel Development Project (P3FH), the SGAR Mempawah Project and the Project Anode Slime \& Precious Metals Refinery. Antam has also built a partnership with Inalum for the Smelter Grade Alumina Refinery (SGAR) project in Mampawah, West Kalimantan. Antam will also increase its ferronickel production capacity from 18,000-20,000 TNi to 27,00030,000 TNi per year through P3FP.

The successful development of Antam entire project will certainly increase its contribution significantly to state revenues. Referring to all the explanation above, it is obvious that Indonesia has adopted a strategic national policy in its mining sectors by issuing the Minerba Act, and deliberately initiated to support its mining downstream sectors. Undoubtfully, the policy reform will be beneficial for Indonesian economy sustainability and thus it should be protected from any potential ISDS claims in the future. As shown in Table 1 in the previous section, six of seven ISDS cases toward Indonesia have taken place in extractive or mining sectors, and only Rafat Ali case is related with other sectors. Out of six ISDS cases in extractive or mining sectors, three cases took place before Minerba Act came into effect and the other three have happened afterwards. The last case - which is still in tribunal process - is specifically related with the implementation regulation of the Minerba Act. The issuance of policy reform in Indonesian mineral mining has clearly triggered one ISDS case, and it is not unlikely that next ISDS cases opposing this law will occur in the near future. Indonesia should anticipate the possibility and it should endeavour to understand thoroughly the upcoming challenges and possible solutions to address such challenges.

\section{Challenges in Benefiting ISDS Mechanism}

Despite the opposition from many developing countries, the World Bank decision to standardize ISDS adoption in BITs and IIAs is anyhow based on goodwill from the perspective the institution had at the moment. In the absence of common ground, with the existing provision of ISDS schemes, it is hoped that an independent, impartial and fair court forum for investors and government will be established, which does not carry an unnecessary burden of political issues and is able to focus on disputed legal issues. Investors should not be concerned about the existence of partial, unfair local court treatment or the compulsion to influence their home countries to provide political intervention through diplomatic channels. On the other hand, the small investment destination countries with low bargaining power in international diplomacy also need not worry about the political pressure and lobbies of 'strong' home countries, the countries where the investors are domiciled. Currently, ISDS provisions are generally included in the most of international investment agreements (including BITs) and free trade agreements. These provisions provide foreign investors with the right to activate the ISDS system, if they wish to counter the host country's decisions that impact on their investment.

Those supporting ISDS and the participation in ICSID suggest three arguments: 1) the ISDS mechanism still makes the host states accountable under BITs, 2) the provisions in the BITs protect fundamental rights of investors and ensure procedural fairness, and 3) the adjudication through the ISDS involve arbitrators who are not formally connected to the parties to the dispute. It shows that the ISDS mechanism can contribute to the rule of law. However, the looming negative sentiment in European countries and Australian shows contrary facts with the spirit of maintaining the existence of the ISDS mechanism. As a matter of fact, the two EU pillar countries i.e. France and Germany have shown their concerns about the effect of ISDS provisions during the Trans-Atlantic Trade and Investment Partnership (TTIP) negotiations between EU and USA. It is awkward to see that this time France and Germany (the latter is prominently known as the pioneer country of ISDS provisions) wish investor-state dispute resolution (ISDS) provisions removed from TTIP agreement currently under negotiation (Provost \& Kennard, 2015).

Australia in the case of a particular IIA also has shown concerns and wishes similar thing (Setiawan, 2018). Those criticizing ISDS show various concerns with the current ISDS practice. The issues vary from financial 
burden to developing country, corporate profit-seeking from the claim, sovereignty, policy space, uneven business playing field, to legislative resistance. In current ISDS practice, developing countries are in the disadvantaged party compared to the developed countries. Gallagher \& Shrestha, (2011) study shows that in the tribunal verdicts on ISDS disputes, developing countries are potentially exposed to higher financial charges than developed countries. The average financial charges that developing countries have incurred for awarded damages to foreign investors are US\$ 99 cents per capita, which is eight times those of developed countries that have incurred only US\$ 12 cents per capita. International investment treaty arbitration takes more time and significantly costs more than resolving similar disputes in domestic courts in the United States or in the United Kingdom (Bonnitcha, 2017). Foreign investors currently tend to register a claim benefiting ISDS clause more frequently, and IIAs with ISDS are beginning to have serious repercussions for developing countries (Knoerich \& Berger, 2014).

In many cases, foreign investors' motives filing their lawsuit to international arbitration are not only to recover the invested funds, but also for the alleged loss of profits and the loss of "future earnings expectations". On average, one of three cases concluded at ICSID ends with dispute resolution. While the rewarded damages value is often not disclosed in detail, the disputes generally result in huge benefits for investors. The state must pay after the ISDS arbitration decision that wins foreign investors, otherwise the state assets will be the seizure target in almost every country in the world (Provost \& Kennard, 2015). Knoerich \& Berger, (2014) mentions that the provisions in IIAs may potentially override national legislation and the decisions of international arbitration may possibly supersede the decision of domestic courts. In this context, they regard that the current IIA regime has sometimes appeared to be superior to national law. If not taken carefully, ISDS disputes potentially disrupt a country's sovereignty and its right to regulate in its territory, as foreign investor pressure may force the government to change the law to please the investor. Tobacco companies regularly threaten investment treaty arbitration when governments propose new tobacco control measures, although some countries have proceeded with stricter tobacco control measures amidst such threats (Berger, 2015).

Jailani, (2015) argues that most provisions of the existing IIAs containing ISDS are outdated as they grant extensively broad protections and rights for foreign investors, yet on the other hand leaving little to no policy space to the host state in achieving development goals. The current regime of IIAs is viewed not granting sufficient space for sustainable development. The situation is an impetus that a general modernization is necessary in order to preserve the right of states to exercise their regulations and policy space. He also stated that ISDS provisions seem to be problematic and their benefits are far from clear. Uneven playing fields between national and foreign corporations also take place, meanwhile the inclusion of ISDS provisions will be a highly contentious issue in the ratification process involving legislative. In the context of Indonesia's concerns with ISDS provisions, some legal experts (such as Prof. Hikmahanto from University of Indonesia) and researchers (such as Ina Primiana from LP3E Kadin) have even accorded extreme advice to the Indonesian government to quit the World Bank's ICSID membership, which also means to quit from ISDS mechanism.

Reflecting on some of the ISDS cases in Indonesian experience, ISDS mechanism may potentially be used by 'rogue' and 'naughty investors' who make the case to the international arbitration panel (Birdieni \& Kiansantang, 2014)-a similar experience also occurred in South Africa case (Provost \& Kennard, 2015). The release of Indonesia from ICSID will allow Indonesia to be free of any legal challenge filed by investors in the forum. Some Latin American countries namely Bolivia, Ecuador, and Venezuela have committed the action first. The ICSID lawsuit trial will cost some compensation (such as lawyer fee) that is not a small one even if Indonesia wins in a case. If Indonesia loses a case, the amount of awarded damages for claimant investors and costs that Indonesia incurs will be even more terrible since it reaches millions of USDs. Losari \& Ewing-Chow, (2015) suggests a different perspective. The authors believe that Indonesia should continue to have ISDS mechanisms, either institutional or non-institutional arbitration. The experience of other countries shows that the ISDS mechanisms, including ICSID arbitration, may actually contribute to better governance. In Mexico, local government tends to comply with domestic and international legal obligations after the local regulations trigger investor-state dispute. The concern for arbitration in ISDS has been successful in making host states comply with their IIAs obligations in an effective, neutral, and independent forum for the settlement of investment disputes (Schill, 2015; Mildner, 2015). 


\section{Putting out the Fire before It Spreads}

In the ICSID forum, Indonesia has been sued by foreign investors in at least seven cases as shown in Table 1. It puts Indonesia in the top rank country of the highest number of international arbitration cases in ASEAN, above the Philippines in the second place with three cases. Such facts forced the Indonesian government to contemplate the right policies to address ISDS problems potentially emerging from foreign investment. Considering all the explanations above, the authors view that the emphasis is on addressing ISDS hidden problems should be focused in prevention endeavour. Policy options necessary to be taken for ISDS cases prevention endeavour are discussed below. Better coordination is necessary among all stakeholders: central and regional governments, relevant ministries, especially when a measure may have impacts on foreign investors. Information technology should be involved in coordination efforts including in compiling and disseminating existing regulations among officials.

A Review of BITs and IIAs Containing ISDS Provisions: Indonesia is currently reviewing comprehensively it's 64 Bilateral Investment Treaties (BITs) as well as five investment chapters under various free trade agreements. The review process involves three steps: discontinuation of existing IIAs, reassessing the provision of the existing IIAs and developing a new treaty model of IIA. The first step taken by Indonesia is to discontinue its existing IIAs and the revoke process so far has reached 17 out of 64 IIAs. The termination takes a gradual approach in order to avoid any unwanted political implications and bilateral backlash that might potentially undermine Indonesia's position. The second step of Indonesia review completely relates to the fact that the core gravity of the review is the reassessment of the existing provisions. Every single IIA is scrutinized to capture the most potential problems in BITs and IIAs provisions, such as the 'scope' and 'definition of investment', the 'Most-Favored-Nation (MFN) Treatment' principle, 'National Treatment (NT)' principle, 'Fair and Equitable Treatment (FET)', 'expropriation' and ISDS. The goals of reassessment are identifying problems and obtaining the most feasible solutions serving as the Government's new position on IIAs, particularly the extent to which those provisions provide protection to the investors and its impact to the policy space of the Government.

The third step is developing a Treaty Model. The goal is to provide a guideline for Indonesian officials in negotiating and concluding investment treaties. Other countries such as India and South Africa have successfully built their own treaty models (Jailani, 2015). Losari \& Ewing-Chew, (2015) views that the Indonesian government's BIT review is timely. They argue that there should be a balance between investor protection and national sovereignty in the new BITs. Several clauses in Indonesia's existing BITs need more clarity, which can potentially lead to difficulties for tribunals in interpreting the provisions. For illustration, the purpose of the agreement should be clearly mentioned in favor of not only for investors but also for greater economic cooperation, or extending and intensifying mutual economic relations. Foreign investment protection is not the individual goal of the treaty, but rather a necessary element alongside the overall aim of encouraging foreign investment and extending and intensifying the parties' economic relations. A balance between investor protection and the state's policy space with a view to promoting sustainable development principles should be upheld and translated into the purpose of the agreement.

In taking this review, Indonesia needs no worry losing potential foreign investments. There is no evidence that foreign investors will pack their bags and leave due to their resistance to host country's measure of review on BITs and IIAs containing ISDS provisions. Several countries - both developed and developing countries - have sought to reform their model treaties and either to negotiate more balanced IIAs in future or renegotiate existing ones and this policy option has no impact on the country's attraction to foreign investors (Bonnitcha, 2014a) in Berger, (2015). In reviewing BITs and IIAs, Indonesia needs to undertake a critical evaluation to comprehend the impact of existing IIAs on the Indonesian national economy. The government also needs to formulate a new approach towards IIAs, which will be fine-tuned in favor of its interest in pursuing national development goals. In the diplomatic relation area, Indonesia brings economic diplomatic mission aiming at creating a new regime for investment agreements between Indonesia and other countries. In association with MFN, NT, FET, expropriation, and ISDS, in order to avoid potential dispute with foreign investors, several important clauses adopted in existing IIAs are worth to discuss as possible solutions. 
Indonesia needs to protect itself from any potential dispute with foreign investors from several aspects relevant with consistency: inconsistency between central government regulations and local government regulations, between the treaty and GATS, and among chapters (Setiawan, 2018). In order to maintain the consistency between an investment treaty and national measures or local government measures, Indonesia may include such reservations: existing non-conforming measures of all regions of Indonesia" in nonconforming measures (BITs and IIAs) and future measures (only IIAs). Such reservations can be found in some FTA agreements, such as Singapore-US FTA, Japan-Mexico FTA, and Australia-Singapore FTA. It is an important issue since under current Indonesia's laws on decentralisation, local governments have the authority to issue business licenses. Meanwhile, business licensing by local governments has been at the heart of several of Indonesia's arbitration cases (Magiera, 2017). The issue of consistency between the investment treaty with GATS must also be taken carefully by Indonesia. In GATS there is particularly energy services sectors which are possibly related with some issues in extractive sectors, especially oil and gas mining. By adopting a similar clause employed in Singapore-US FTA and Canada-Peru FTA, Indonesia may add some reservations in the non-conforming measures schedule as follows. Reserves the right to adopt or maintain any measure that is not inconsistent with Indonesia's obligations under Article XVI of the General Agreement on Trade in Services. The consistency between chapters in an agreement should also be maintained. As an illustration, the substance in transfer-related provisions may differ between chapters in IIAs that contain chapters such as the Investment Chapter, Trade in Goods Chapter, and Services Chapter. A BOP (Balance of Payment) safeguard clause is also at times found only in one of the chapters, whereas this clause should be included in the three chapters. Transfer and safeguard BOP clauses are critical to being included in the main chapters, given such clauses are crucial for developing countries to protect their economy during the crisis. While clauses in the terminated BITs above can be revised during the next negotiations, this is not the case for existing investment chapters under Free Trade Agreements (FTAs) or Economic Partnership Agreements (EPAs). Indonesia should wait until the FTAs or EPAs comes into general review phase or are terminated consensually. If the scenario takes place, it is recommended that Indonesia includes a clause allowing partial termination of a chapter, particularly the investment chapter in the FTAs or EPAs. Other clause needs attention is the existence of 'survival clause'. This clause allows foreign investors, who have had their investments made or acquired before the date of termination, to benefit prolonged protection for a certain amount of time (usually 10 - 15 years) even after termination of the treaty.

Improvement in Investment Dispute Management: Reflecting the fact that Indonesia topped the country with the most ISDS lawsuits among ASEAN member countries, it is crystal clear that Indonesia needs to improve its management of investment disputes. In that regard, the development of investor-state conflict management, a basis for protocols for dispute avoidance is suggested. These processes are intended to provide ways out for the interests of the parties involved in the early stage of the conflict to eliminate or reduce the source of dissatisfaction. Another way out associated with procedural limitations can be helpful, such as developing a special agreement between the investor and Indonesia if the case should be registered to international arbitration. Establishing an investment dispute management unit has been applied to other countries such as Korea and Peru. Korea created the Office of the Foreign Investment Ombudsman within the Korea Trade-Investment Promotion Agency, an office independent and only accountable to the Prime Minister. The office facilitates foreign investors who face problems or conflicts in several issues, such as taxation, investment procedures and incentives, customs and tariffs, finance, labor, insurance, and visa. In Peru, such an office imposes accountability on the agency which has triggered the dispute by incurring any costs of the process (Losari \& Ewing-Chew, 2015).

Indonesia Needs for Continuous Bureaucracy Reform, Capacity Building, Better Coordination: Indonesia bureaucracy reform is still ongoing, yet there are still many weakness identified along the reform process. It should be realized that bureaucracy reform is a never-ending process and this effort should always be a priority and continuously supported by every elected national leader. Politicians may change, but the bureaucracy reform should never stop. Without robust, efficient, and effective bureaucracy, every government program including management of investment disputes and better coordination cannot be achieved successfully. Capacity building for Indonesian officials Indonesia should be prioritized. Processes should be generated to keep bureaucracy system involving those officials aware of reviewing each proposed government's measure, either in state or local government level, that may affect foreign investors, and its compliance with Indonesia's international obligations under its IIAs, before a particular measure becomes 
effective. The process should invite public consultation with interested parties, including investors or the society who might be impacted. The government then should take the inputs and comments into consideration for the measure revision. Potentially arising dispute could be prevented effectively in the beginning to assure the investors do not appeal the investment dispute case to international arbitration.

\section{Conclusion and Recommendations}

ISDS mechanism adoption in BITs and IIAs was initiated in the late 1960s and the beginning of 1970s. Despite 21 developing countries opposition, World Bank decided to support the mechanism and provides a specific tribunal for ISDS by establishing ICSID in 1966. While in the beginning the investors appeal for ISDS was seemingly intended purely to reclaim justice, currently investors in several cases register allegedly frivolous claims to international arbitration. Indonesia does not escape the ISDS lawsuit, and even among ASEAN member countries Indonesia topped the number of ISDS suits filed in ICSID. Indonesian reform policy to support more its mining downstream by Minerba Act issuance is based on its national interest seeking to benefit from its scarce, limited non-renewable minerals so as to support national development and maintain its long-term economic sustainability. To realize the vision, thus, more specifically Indonesia needs to encourage the establishment of domestic smelters, to integrate upstream-downstream-industrial operations, to increase mineral added value, and to boost state revenues. Benefiting from ISDS inclusion in BITs or IIAs has some challenges, since there are some pros and cons toward the ISDS inclusion.

Those who support ISDS inclusions believe ISDS mechanism is good to make host states accountable under BITs, necessary to protect fundamental rights of investors and ensure procedural fairness, and the adjudication involve independent arbitrators. Meanwhile, the parties who oppose believe that ISDS mechanism will be harmful to and put unnecessary big or even huge compensation burden to host countries. Not only developing host country but also developed host country in Europe and Australia in specific BITs or IIAS cases have proposed no ISDS inclusion. ISDS mechanism may potentially override national legislation and the decisions of international arbitration may possibly supersede the decision of domestic courts. The most frequent ISDS claims which Indonesia has received among ASEAN members surely forced the Indonesian government to envisage the right policies to address the problems potentially emerging from foreign investment. The authors view that the emphasis on addressing ISDS contingent problems should be focused on prevention endeavor. As previously explained in more details and more specifically in the above section, authors recommend the prevention endeavor should be undertaken and focused on the review on BITs and IIAs containing ISDS provisions; improvement in investment dispute management; and continuous bureaucracy reform, capacity building, and better coordination. It is suggested that Indonesia proposes to shorten the time period of such a clause, and different survival clause durations for different sectors of investment.

\section{References}

Antam. (2015). Annual Report, Ikhtisar Kinerja Berkelanjutan Tahun 2015. Jakarta: PT. Antam Tbk (Persero). Antam. (2008). Empat Dasawarsa PT Antam Tbk : Memaknai Alam, Melintasi Masa. Jakarta: PT Antam Tbk. (Persero).

API. (2013). Kontribusi Pertambangan Umum Masih Minim. Asosiasi Pertambangan Indonesia. .

Berger, A. (2015). Developing Countries And The Future Of The International Investment Regime. Deutsche Gesellschaft für Internationale Zusammenarbeit (GIZ) GmbH.

Birdieni, B. \& Kiansantang, J. (2014). Buron Century Tanpa Kemenangan. Gatra, 24 Desember 2014.

Bonnitcha, J. (2017). Assessing the Impacts of Investment Treaties: Overview of the Evidence. International Institute for Sustainable Development.

Burmeister, B. B. (1988). From Resource to Reality: A Critical Review of the Achievements of New Australian Gold Mining Projects During the Period January 1983 to September 1987 . Macquarie University.

Djafar, F. \& Rosdiana, H. (2013). Evaluasi Kebijakan Bea Keluar atas Barang Ekspor Mineral : Tinjauan Terhadap PMK No.75/PMK.011/2012. Jakarta: Fakultas Ilmu Sosial dan Ilmu Politik Universitas Indonesia.

Freeport McMoran, Inc. Annual Reports. (2006-2014). 
Gallagher, K. \& Shrestha, E. (2011). Investment Treaty Arbitration and Developing Countries: A Re-Appraisal. Global Development and Environment Institute Working Paper No. 11-01.

Harquail, D. (1991). Investing in Junior Mining Companies. Proceedings of the 6th Mineral Economics Symposium of CIM. CIM Montreal Canada.

Ika, S. (2017). Kebijakan Hilirisasi Mineral: Reformasi Kebijakan untuk Meningkatkan Penerimaan Negara. Kajian Ekonomi Keuangan, 1 (1).

Jailani, A. (2015). Indonesia's Perspective on Review of International Investment Agreements. Investment Policy Brief No, 1.

Kementerian ESDM. Laporan Kinerja Tahun. (2015).

Kementerian Keuangan. APBN dan Laporan Realisasi APBN. (2006-2014).

Knoerich, J. \& Berger, A. (2014). Friends or Foes? Interactions Between Indonesia's International Investment Agreements and National Investment Law. Studies. Bonn: Deutsches Institut fur Entwicklungspolitik.

Latina, J., Permartini, R. \& Ruta, M. (2011). Natural Resurces and Non Cooperative Trade Policy. International Economics Policy, 8.

Losari, J. \& Ewing-Chew, M. (2015). Reflective or Reactionary? Indonesia's Approaches to International Investment Agreements and Recommendations for the Future. Transnational Dispute Management, 12.

Magiera, S. L. (2017). International Investment Agreements and Investor-State Disputes: A Review and Evaluation for Indonesia. ERIA Discussion Paper Series.

McCarthy, P. (2013). Managing technical risk for mine feasibility studies in Mining Risk Management. The AusIMM.

Mildner, S. (2015). International Investment Agreements and Investor-State Dispute Settlement: Fears, Facts, Faultlines. BDI - Federation of German Industries.

Miskelly, N. (2004). The International Mining Industry - Linking the Upareams Mineralisation With the Downstream Money. Conference Proceedings, 10-22.

Mohamadieh, K. \& Uribe, D. (2016). The Rise of Investor-State Dispute Settlement in The Extractive Sectors: Challenges and Considerations for African Countries. Research Paper, 65.

Patunru, A. A. (2015). Hilirisasi. Kompas 24 Januari 2015.

Provost, C. \& Kennard, M. (2015). The obscure legal system that lets corporations sue countries. The Guardian, Wed 10 Jun 2015 (downloaded 19 June 2018).

Rahayu, A. (2010). Pengantar Kebijakan Fiskal. Jakarta: PT Bumi Aksara .

Resmini, L. \& Vittucci, G. (2016). Home country bias in divestment decisions of multinational corporations in the EU. Conference Paper. 56th Congress of the ERSA: "Cities \& Regions: Smart, Sustainable, Inclusive?" ?", 23-26 August 2016. Vienna, Austria: Econstor and European Regional Science Association (ERSA).

Rudenno, V. (2004). The Mining Valuation Handbook, 2nd edition. Rightbooks an Imprint of John Wiley and Sons Australia, Ltd.

Saggu, A. \& Anukoonwattaka, W. (2015). Commodity Price Crash: Risks to Exports and Economic Growth in Asia-Pacific LDCs and LLDCs. United Nations ESCAP.

Schill, S. (2015). Reforming Investor-State Dispute Settlement (ISDS): Conceptual Framework and Options for the Way Forward. E15 Initiative. World Economic Forum and International Centre for Trade and Sustainable Development.

Sembiring, S. F. (2009). Jalan Baru Untuk Tambang : Mengalirkan Berkah Bagi Anak Bangsa. Jakarta: PT Gramedia.

Setiawan, S. (2018). Negative List in Services Liberalization: Pros and Cons for ASEAN Developing Economies. Working Paper.

Stijns, J. C. (2001). Natural Resource Abundance And Human Capital Accumulation. Diakses dari https://ageconsearch.umn.edu/bitstream/25128/1/ uccost01.pdf Tanggal 15 January 2017. University of California at Berkeley.

UNCTAD (2014). Investor-State Dispute Settlement: UNCTAD Series on Issues in International Investment Agreements II: A sequel.

Walker, S. (2015). Gold: New Fundamentals. Engineering \& Mining Journal, February 2015.

Ward, D. (1999). Startup Performance of New Base Metal Projects in Adding Value to the Carpentaria Mineral Province. Australian Journal of Mining, April 1999. 